\title{
Larva Development and Growth of Mangrove Crab, Scylla tranquebarica Crablet from Individual Selection for the Broodstock Candidate
}

\author{
Gunarto, M. N. Syafaat and Herlinah \\ ${ }^{1}$ Research Institute for Coastal Aquaculture and Fisheries Extension \\ 90512 Maros, South Sulawesi \\ Email: (First author: gunartom@yahoo.com; second author:syafaat.mnur@gmail.com; Third author: \\ hjompa@yahoo.com)
}

Received: 31 October 2018; Accepted: 26 March 2019

\begin{abstract}
Gunarto, M. N. Syafaat and Herlinah. 2019. Larva Development and Growth of Mangrove Crab, Scylla tranquebarica Crablet from Individual Selection for the Broodstock Candidate. Aquacultura Indonesiana, 20 (1): 24-31. A part of $S$. tranquebarica crablet offspring produced from larvae rearing often grows faster than the others. The research aimed to monitor larvae development and compared the growth between fast and slow growth crablet offspring until broodstock stage and produce female mature gonadal. Research was conducted in mud crab hatchery Reseach Institute for Coastal Aquaculture and Fisheries Extension (RICAFE), located in Barru Regency and Maranak Pond Research Station of RICAFE in Maros, South Sulawesi Indonesia for 14 months from August 2016 to October 2017. F2 hatched larvae from two female F1 broodstocks were reared until crablet stage with 4848 individual production of crablet F2, then 600 individual were weighed and measured of their carapace width. The data figured as a normal distribution curve. 700 ind. of fast growth crablet with average carapace width $15.2 \pm 1.29 \mathrm{~mm}$ and average body weight $0.55 \pm 0.15$ $\mathrm{g} /$ ind. were selected. The others 700 individual slow growth crablet, average carapace width $8.88 \pm 3.11 \mathrm{~mm}$ and average body weight $0.14 \pm 0.08 \mathrm{~g} /$ individual were selected also. These crablet were stocked separately in four soil ponds of size $500 \mathrm{~m}^{2} /$ compartment, each with density 350 ind./pond. Crablet growth was monitored monthly. After five months cultured, the fast growth crablet attained 185.7 $\pm 38.7 \mathrm{~g} / \mathrm{ind}$. and significantly different $(\mathrm{P}<0.05)$ with the slow growth crablet $156.94 \pm 15.30 \mathrm{~g} / \mathrm{ind}$. At the fourth months of culture from the fast growth crablet group was obtained two individual female mature gonadal with weight $205.2 \pm 0.3 \mathrm{~g}$ and carapace width $116.7 \pm 0.7 \mathrm{~mm}$. That female mature gonadal was spawned after $28.5 \pm 2.12$ days incubated in the hatchery. Fast growth crablet is concluded more effective for the broodstock candidate in mud crab hatchery.
\end{abstract}

Key words : Mangrove crab; Scylla tranquibarica; Fast growth; Individual selection

\section{Introduction}

The mangrove crab or mud crab Scylla spp culture in brackishwater pond have been developed in some area, mostly the pond location closes to the mud crab natural resources, such as in pond located near Cenranae mouth river, Bone regency, South Sulawesi (Gunarto and Rusdi, 1993). The mud crab seed (crablet) for cultured come from crabbing in the wild (Gunarto and Rusdi, 1993; Baliao, 2003) as well as from hatchery (Baliao, 2003; Syafaat and Gunarto 2018). In order to develop mud crab grow out in brackishwater pond, the existence and continuously supplied of mud crab seed produced from hatchery could be sufficient to fulfill the seed requirement for cultured in the brackishwater pond. However, up to now, mud crab seed production from hatchery still fluctuated inconsistently due to many factors, one of them is caused by low quality of female mud crab broodstock. The female mature gonad in mud crab hatchery purposed for seed production mostly was obtained from middleman who are selling mud crab to the local market or restaurant consumption. Thus something like waiting for luck to obtained the good quality of egg and larvae produced by these female broodstock, it was caused by unknown quality story of these broodstock.

Up to now still no information about study of mud crab broodstock production through individual crablet selection for mud crab seed production purposed. This study considered very important in order to know the quality story including the growth, age of broodstock when started mature gonadal and 
spawned also produced their offspring. There are some study on broodstock mostly focused on the stimulated gonadal maturation of female mud crab broodstock (Siahainenia et al,. 2007; Azra and Ikhwanuddin, 2016) and broodstock fattening (Macintosh et al., 2008). Initiation of broodstock production through individual crablet selection can be started from crablet D30 produced from nursery system where after crablet harvested often occurred 5-15\% of the seed population with fast growth, whereas the rest crablet with slow growth. Individual selection on mud crab population with superior characteristics such as fast growth is hoped to be able to obtained mud crab stock with superior characteristics for the next breeding program. The research aimed to monitor larvae development and compared the growth between fast growth and slow growth crablet $S$. tranquebarica offspring until broodstock stage and produce female gonadal mature.

\section{Material and methods}

\section{Broodstock maintenance}

In August 2016, female broodstock of mud crab $S$. tranquibarica with gonadal stage III and IV mean body weight $276 \pm 35 \mathrm{~g} / \mathrm{ind}$. were obtained from Malili, East Luwu Regency, West Sulawesi province brought to mud crab hatchery in Marana, Maros regency, South Sulawesi Province, Indonesia. Approximately one week after incubated in the spawning tank filled with sterile saline water salinity $30 \mathrm{ppt}$, some broodstock spawned, then they incubated to hatch their egg. The egg hatched after 10 days incubated in $1000 \mathrm{~L}$ tank filled with $700 \mathrm{~L}$ sterile saline water salinity 30 ppt and aerated. The larvae reared in conical fiber tank volume $250 \mathrm{~L}$ filled with sterile saline water salinity $30 \mathrm{ppt}$. Larvae were fed with rotifer and nauplii artemia. The F1 crablet D-10 produced in December 2016, then stocked in the brackishwater pond located in Marana Brackishwater Pond Research Station, RICAFE, Maros. At April 2017 was obtained some F1 mud crab broodstock female mature gonadal with mean weight $225.80 \pm 55.98$ g/ind. and carapace width $113.85 \pm 7.92 \mathrm{~mm}$. Fifteen individual of that broodstock transferred to the mud crab hatchery in Barru, South Sulawesi. All broodstock were stocked in conical fiberglas tank volume $700 \mathrm{l}$, filled with $600 \mathrm{~L}$ steril saline water salinity 30 ppt. Two female F1 mud crab broodstock spawned almost simultaneously in one day then they incubated in two different tanks volume $1000 \mathrm{~L}$, filled with $600 \mathrm{~L}$ steril saline water salinity $30 \mathrm{ppt}$ and aerated. Monitoring on egg fecundity and hatching rate of $\mathrm{F} 2$ larvae based on the procedure from Churchill which modified as follow, (2003). The F1 crabs were weighted at first day after spawned. Samples of egg were taken using tweezer as much $0.02 \mathrm{~g}$ (three replicates) from an individual spawned crab, then counted egg numbers. Thus the total eggs number in an individual spawned crab can be calculated by interpolated number of egg in a sample mean weight to the total whole egg number in the spawned crab after obtained the whole weight of egg in a spawned crab. The whole weight of egg can be obtained after all egg hatched and the crab reweighed. Total whole egg weight as well as total egg number per individual spawned can canculated as follows :

$$
\mathrm{TEW}=(\mathrm{NE}-\mathrm{NH})+(\mathrm{Z})
$$

TEW : Total Whole Eggs Weight (g), NE : Spawned crab weight at the first day $(\mathrm{g}), \mathrm{NH}$ : $\mathrm{Crab}$ weight after all eggs hatched $(\mathrm{g}), \mathrm{Z}$ : estimated egg loss caused fall out ( $\mathrm{g}$ )

Hatching rate calculated as follows :

$100 \mathrm{ml}$ sub samples water with larvae encounterd (minimum three replication) were taken from the tank and the larvae number were counted manually. The number of viable larvae in the tank calculated using equation

$$
\mathrm{NVL}=(\mathrm{M} \times \underline{\mathrm{VT}})
$$

NVL : number viable zoea, $\mathrm{M}$ : the mean number of zoea in the sub sample, VT : volume of the tank, VS : volume of the sub sample

$$
\text { Hatching rate }=(\mathrm{NVL} / \mathrm{F}) \times 100 \%
$$

$$
\begin{array}{cl}
\text { NVL } & \text { : Number viable larvae } \\
\text { F } & \text { : fecundity }
\end{array}
$$

\section{Fast growth and slow growth crablet selection}

New hatch larvae were reared until megalopa and crablet stage followed the procedure from Gunarto et al. (2016). Water quality monitored in larvae rearing namely: salinity, Total Organic Matter (TOM), water $\mathrm{pH}$, ammonium, nitrite and population of Vibrio sp. 
F2 crablet production then reared in the nursery until D-30. 600 ind. of F2 crablet D-30 were weighted using a digital balance with accuracy of $0.01 \mathrm{~g}$ and measured the carapace width using a caliper with accuracy of $0.1 \mathrm{~mm}$. The data obtained then tabulated and figured as the normal distribution curve represented the F2 crablet size distribution. Cut off $5-15 \%$ of normal distribution crablet D30 population mainly on the crablet with fast growth and also cut off $5-15 \%$ of normal distribution in the crablet D30 population with slow growth. Both of the selected crablet group then transported from Barru to Marana Brackishwater Pond Research Station of RICAFE Maros for grow out. Dry system crablet transportation was applied, where crablet was spread in some numbers of the wet cutting black net $(20 \times 20$ $\mathrm{cm})$ placed inside styrofoam.

\section{Crablet grow out}

Four brackishwater ponds compartment each size $500 \mathrm{~m}^{2}$ located in Marana Research Station of RICA Maros prepared for mud crab grow out. Pond preparation have been conducted including pond bottom drying, the application of saponin at $20 \mathrm{ppm}$ to eliminate predatory fish before crablet stocked in the pond and fencing using black net plastick around pond dike to prevent mud crab escape from inside the pond. The pond filled with saline water through the inlet coincides with a few days in the high water of tidal cycle. The water depth in the pond at about $40 \mathrm{~cm}$, then fertilizer (urea and SP-36) were applicated followed Gunarto et al. (2010). The F2 crablet was stocked separately in these four pond with stocking density of 350 ind./pond. Fast growth crablet and slow growth crablet grow out was tested with the two replications. At the second month of culture the chopped trash fish was given to the crab in the pond at the dosage 5\% of total body weight. In the consecutive month the feed percentages given to the crab in pond was decreased until $2.0 \%$ of total body weight at the fifth month of culture. The growth of the mud $\mathrm{crab}$ in four ponds were monitored monthly by catching 30 ind. of mud crab using trap net with bait fish inside the trap. The mud crab caught were weighed using a digital balance with accuracy of $0.1 \mathrm{~g}$ and measured carapace width using the caliper with accuracy of $0.1 \mathrm{~mm}$. Female mature gonadal monitored by looking on swollen of upper carapace crab trapped beginning after three month of culture.
The female mature gonadal then measured their weight and carapace width, furthermore the crab incubated in hatchery in order to spawn and hatched their egg. Water quality monitored in crablet grow out in brackishwater pond namely: water $\mathrm{pH}$, salinity, dissolved oxygen and water temperature.

\section{Data analysis}

Hatching rate, larvae production, larvae survival rate, megalopa and crablet production data were analyzed descriptively. Growth data obtained from measuring crab weight and crab carapace width which obtained monthly during five-month crab cultured in the pond were compared and tested using T-test, while water quality data were analyzed descriptively.

\section{Results}

\section{Larvae development and crablet production}

The F1 broodstock size with carapace length $72,45 \pm 2,74 \mathrm{~mm}$, carapace width $104,36 \pm 5,31 \mathrm{~mm}$ and body weight $226,5 \pm 19,65$ $\mathrm{g}$ spawned with egg fecundity $926.808 \pm 328.212 \mathrm{egg}$ and hatching rate was $67.51 \pm 25.92 \%$. F2 Larvae was reared in the conical fiberglass tank volume $200 \mathrm{~L}$ at the density 100 ind./L. Decreasing larvae population until megalopa stage presented in Figure 1a. At the zoea-5 stage, the larvae density attained 34 ind./L. Megalopa emerged started at 15 days of rearing then megalopa thinned to the numbers of the bigger fiberglass tanks (volume $3000 \mathrm{~L} / \mathrm{tank}$ ) to minimizing cannibalism between megalopa and megalopa to the zoea-5. The megalopa density on the first day was four ind./L and at the third day was decreased into one ind./L as presented in Figure $1 \mathrm{~b}$. Water quality parameters monitored in the larvae rearing namely ammonium at $0.13-0.79 \mathrm{mg} / \mathrm{L}$, nitrite at $0.0008-0.61 \mathrm{mg} / \mathrm{L}$ and total organic matter at $16.89-33.15 \mathrm{mg} / \mathrm{L}$. Salinity 30-32 ppt, water pH 0.78-0.80. and the higher Vibrio sp population was $10^{3} \mathrm{CFU} / \mathrm{mL}$. 


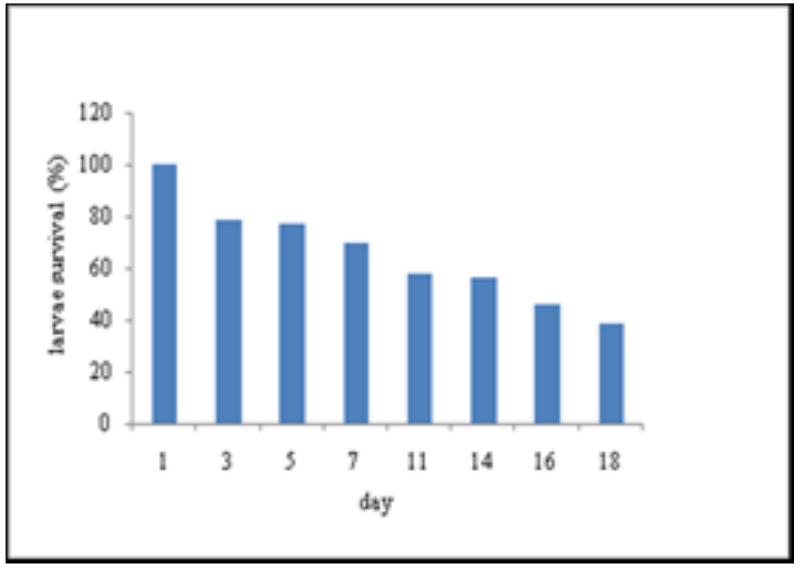

(a)

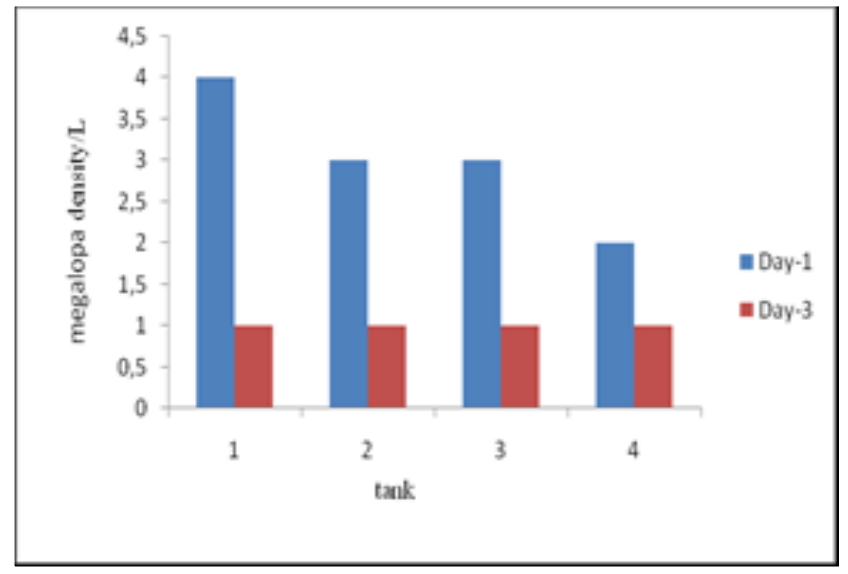

(b)

Figure 1. Decreasing larvae population until zoea-5 stage (a), megalopa density after thinned to the four fiberglass tank each volume 3 ton (b).

The crablet-D1 started emerged at the day 25 of larvae rearing and the total of 4848 individual crablet-D10 harvested at the day-35 and then they are reared in the nursery until D30 using the four cement tank each size $2 \times 3 \times 1.2 \mathrm{~m}$ filled with 3 ton sterile saline water salinity 32 ppt.
Based to the normal distribution curve F2 crablet-D30 population (=700 ind.) was obtained that fast growth crablet with mean body weight $0.55 \pm 0.15 \mathrm{~g} / \mathrm{ind}$ and mean of carapace width $15.2 \pm 1.29 \mathrm{~mm}$, whereas slow growth crablet with the mean body weight $0.14 \pm 0.08 \mathrm{~g} / \mathrm{ind}$. and the mean of carapace width $8.88 \pm 3.11 \mathrm{~mm}$ (Figure 2).

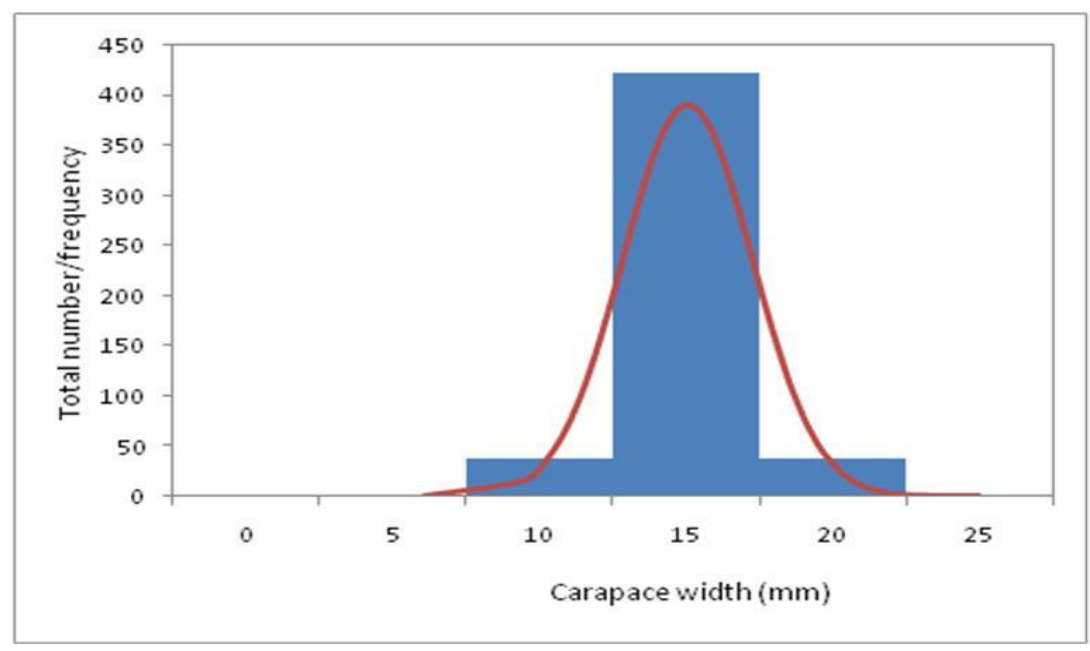

Figure 2. Normal distribution curve of S. tranquebarica crablet carapace width

\section{Crablet grow out in brackishwater pon}

The F2 fast growth crablet started from mean weight $0.55 \pm 0.15 \mathrm{~g} / \mathrm{ind}$., carapace width $15.2 \pm 1.29 \mathrm{~mm}$, whereas $\mathrm{F} 2$ slow growth crablet started with the mean weight $0.14 \pm 0.08 \mathrm{~g} / \mathrm{ind}$., carapace width $8.88 \pm 3.11 \mathrm{~mm}$ after five months cultured in the brackishwater pond, the crab weight was attained $185,7 \pm 38,7$ g/ind., carapace width $10,45 \pm 0,35 \mathrm{~cm}$. And of
$156,94 \pm 15,30 \quad$ g/ind., carapace width $10,40 \pm 1,41 \mathrm{~cm}$ (Figure 3a:3b). Specific daily growth rate was $1.74 \% /$ day for the fast growth crablet and $1.46 \%$ /day for slow growth crablet. The water quality parameters measured during mud crab culture from June to October 2017 in Marana brackishwater pond research station of RICA Maros namely; salinity 35-48 ppt, $\mathrm{pH}$ :88.5 , water temperature $28-31^{\circ} \mathrm{C}$ and alkalinity $120-160 \mathrm{mg} / \mathrm{L}$ 

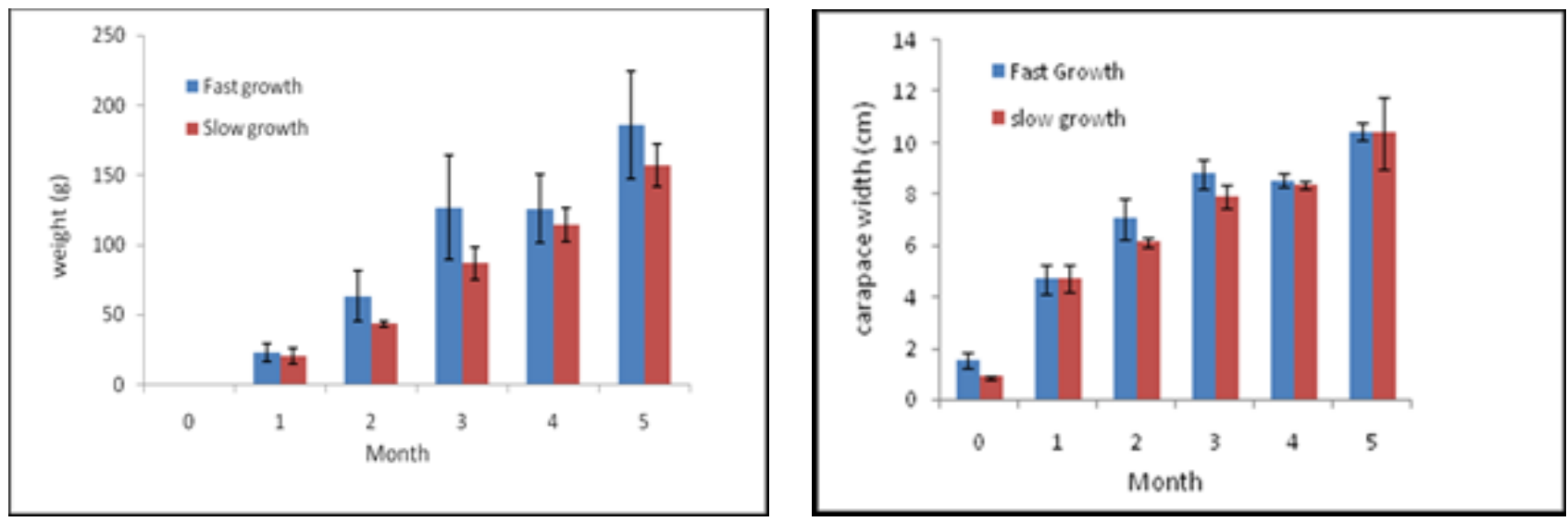

Figure 3. The growth of total body weight (g/ind) (a) and growth.of carapace width (cm) (b) of fast growth crablet and slow growth crablet group cultured during five months cultured in Marana brackishwater pond research station of RICAFE Maros

\section{Broodstock Candidate}

Some F2 female mud crab with gonadal mature stage II with weight $205.2 \pm 0.3 \mathrm{~g}$ and carapace width $116.7 \pm 0.7 \mathrm{~mm}$ was obtained from the fast growth crablet group at the fourth months of culture and it was signed with the swollen upper carapace (Figure 4), The female swollen mud crab reared in spawning tank in mud crab hatchery and spawned after $28.5 \pm 2.12$ days. At 10 days after incubated in hatching tank, the F3 new larvae hatched with the hatching rate approximatly $98 \%$ from the egg fecundity and produced $1.410 .000 \pm 137885$ ind. larvae. .
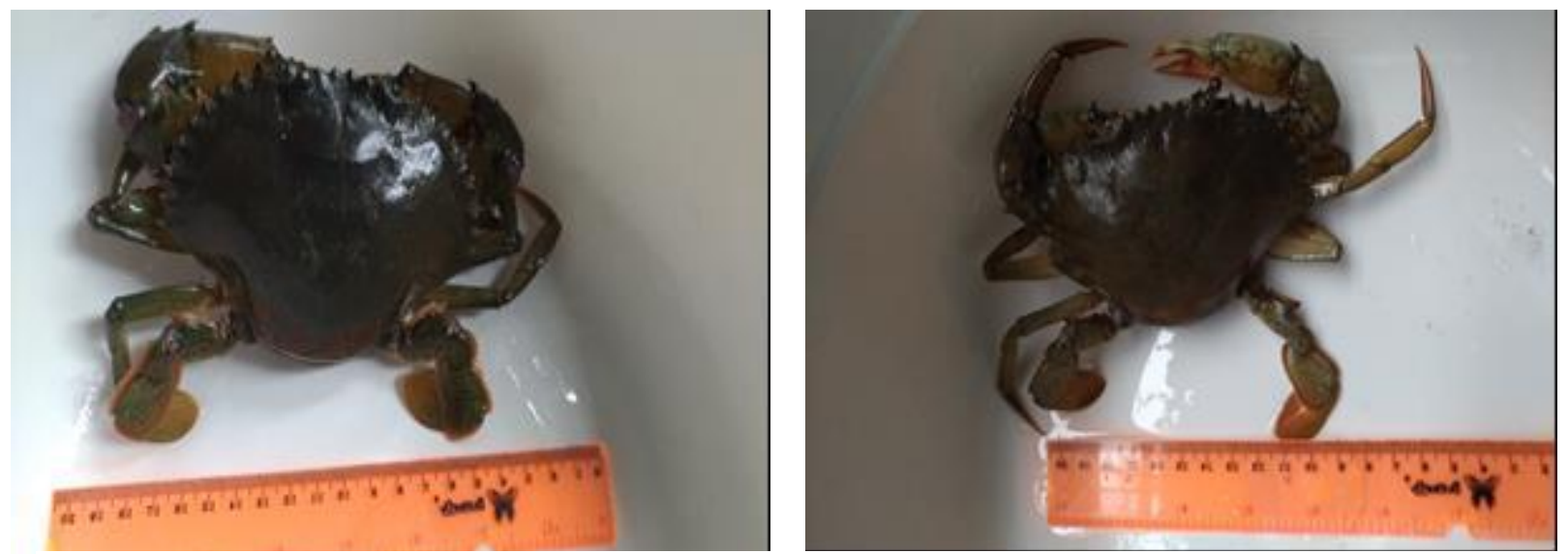

- Figurer 4. Broodstock (female mature gonadal caught from the crablet fast growth group after four month cultured in Marana brackishwater pond research station of RICAFE Maros.

\section{Discussion}

It seemed low numbers of larvae production $\quad(625.688 \pm 162.178$ individual larvae), from the female broodstock with carapace $113.85 \pm 7.92 \mathrm{~mm}$ and mean weight $225.80 \pm 55.98 \mathrm{~g} / \mathrm{ind}$., may be caused by the first time for the broodstock to spawned their egg after attained adult size. The bigger size of broodstock will produce the higher numbers of larvae production. Churchill (2003) reported that $S$. serrata broodstock in Natal, South Africa which carapace width 131-141 mm, egg fecundity attained to $4.03 \pm 1.17$ million egg, while the crab with carapace width 146$181 \mathrm{~mm}$ with egg fecundity $7.98 \pm 1.79$ million egg. Larvae survival rate until zoea 5 stage in this research was $31,8 \%$. The larvae survival rate was higher compared to that early research namely only 27,5\% (Gunarto and Herlinah, 2015). The larvae survival rate was influenced by natural feed density, such as rotifer, Brachionus plicatilis which given to the zoea-1 until zoea 3 stage hopely at the density 20-40 
ind./mL. Truong et al. (2007) reported that rotifer density at 45 ind./mL would result high larvae survival rate, while at the rotifer density 60 ind./mL would result in fast larvae development. In this research rotifer density was given to the larvae until zoea 3 stage at the density only $15-25$ ind./mL and Artemia nauplii which given to the zoea 3 stage until megalopa stage at the density 1-3 ind./mL. HUFA enriched to the rotifer and Artemia nauplii before both of them given to the larvae (Suprayudi et al. 2002; Suprayudi et al. 2004; Karim, 2006; Shigeki and Hamazaki, 2012; Gunarto and Herlinah, 2015). The healthy larvae would also influencing to the fast larvae development. Larvae with dense of the parasite such Zoothamnium sp would develop late attained megalopa stage more than day 20 or will die before attained consecutive stage.

In this research the megalopa stage started at day-17 of larvae rearing. In earlier research for the larvae $S$. paramamosain rearing, the megalopa stage started at the day 23 (Gunarto and Herlinah, 2015). Fast larvae development in this research may be caused by sufficiently of natural feed suplay (rotifer, Brachionus plicatilis and Artemia nauplii) which given to the larvae and also larvae feed substituted with commercial artificial feed started when larvae attained the zoea-3 stage and continuous until larvae develop to zoea 5 (Gunarto et al. 2018). Cannibalism between megalopa and megalopa or megalopa to the zoea 5 often occurred in the rearing tank. Thinning was conducted by separated some megalopa to a few numbers of a bigger tank. In this research megalopa thinned to the four fiberglass tanks each volume three ton with megalopa density 3-4 ind./L at the day-1, then megalopa population was decreased to 1 ind./L in the third day of rearing caused mortality and some megalopa have sedentary to the bottom of the tank. Started from the day 7 of megalopa rearing the crablet first instar emerging in the tank bottom, that means first instar crablet (crablet D-1) was found at the day 7, furthermore after D-10 the crablet harvested from the bottom tank.

High mortality of megalopa often obtained when megalopa sedentary in the tank bottom to metamorphosis from the megalopa stage to the crablet stage. In this cases high Vibrio sp population $\left(>10^{3} \mathrm{CFU} / \mathrm{mL}\right)$ in the water was responsible to the minimizing megalopa success metamorphosis to the crablet stage.

Growth monitoring showed that fast growth crablet is really higher growth rate compared than slow growth crablet during 150 days cultured in brackishwater pond at the density 350 ind. crablet $/ 500 \mathrm{~m}^{2}$. Final weight was $\quad 185.676 \pm 38.74 \mathrm{~g} /$ ind. significantly $(\mathrm{P}<0.05)$ growth faster compared than the slow growth crablet group with final size only attained $156,944 \pm 15.30 \mathrm{~g} / \mathrm{ind}$. Hendrajat and Gunarto (2013) found that mud crab S. olivacea reached carapace width and total body weight was $10.7 \mathrm{~cm}$ and $207.5 \mathrm{~g} /$ ind respectively and $S$. paramamosain reached carapace width and total body weight was $11 \mathrm{~cm}$ and $215 \mathrm{~g} / \mathrm{ind}$. after 195 days in the pond with salinity 30-40 ppt from initial size $0.03 \mathrm{~g} / \mathrm{ind}$.

The growth rate of mud crab in brackishwater pond influenced by many factors such as water quality, stocking density, besides continuous feed supplied in the pond. Mia and Shah (2010) reported that the specific growth rate of $S$. serrata as salinity $25 \mathrm{ppt}$ was $4.46 \% /$ day. Futhermore, Gunarto and Suryanto (2014) reported that spesific growth rate of $S$. tranquebarica in pond of Marana Research Station, Maros at salinity 30-45 ppt was only $2.53 \% /$ day, whereas S. olivacea was lower only $1.191 \% / d a y$. Syafaat and Gunarto (2018) reported that specific growth rate of $S$. tranquibarica were $2.39 \% /$ day; $2.53 \% /$ day and $2.09 \% /$ day for the mud crab growth in Maros, Pangkep and Polmas brackishwater pond with salinity at the ranged 10-30 ppt; 15-25 ppt; 1021 ppt respectively. Mud crab $S$. tranquibarica in this research with specific growth rate of $1.74 \% /$ day for the fast growth crablet and $1.46 \%$ /day for slow growth crablet. Pond salinity in this research was too high at the range between 35-48 ppt during cultured, caused mud crab growing slow and also low survival rate namely $30-35 \%$ in all treatments. Sandeep and Kurva, (2014) reported that salinity is the main factor influenced to the growth and survival rate of mud crab, $S$. tranquebarica cultured in brackishwater pond and salinity optimum for the growth is 15-25 ppt.

At the fourth months of mud crab culture in this research was find out the first female mature gonadal stage with weight $205.2 \pm 0.3 \mathrm{~g}$ and carapace width $116.7 \pm 0.7 \mathrm{~mm}$ from the fast growth crablet group and after the fifth month the crab had been spawned and produced larvae with the hatching rate approximatly $98 \%$ from the egg fecundity and the larvae production was $1.410 .000 \pm 137.885$ ind.. From this finding was proved that mud crab $S$. tranquebarica from fast growth crablet group able to produced new generation after sixth month in their life cycle and by the individual selection able to 
produce higher larvae population. In contrary, the slow growth crablet group until fifth months culture period in brackishwater pond, there were not found the female mud crab with mature gonadal stage.

\section{Conclusions}

- Larvae survival rate until zoea 5 stage was $31,8 \%$ and the first megalopa stage emerged at 15 days of rearing, then the first crablet-D1 emerged at the day 25 of larvae rearing and the total of 4848 individual crablet-D10 were harvested at the day-35.

- Fast growth crablet group after five months cultured in brackishwater pond with final weight $185.676 \pm 38.74 \mathrm{~g} / \mathrm{ind}$. is significantly growth faster $(\mathrm{P}<0.05)$ compared than the slow growth crablet group with final weight $156,944 \pm 15.30$ g/ind.

- The broodstock candidate represented by the female mature gonadal stage from the fast growth crablet group with mean weight $205.2 \pm 0.3 \mathrm{~g}$ and carapace mean width $116.7 \pm 0.7 \mathrm{~mm}$ was obtained at the fourth months of culture in brackishwater pond. Then they spawned after $28.5 \pm 2.12$ days incubated in the spawned tank. So that approximately at the sixth month period of culture the mud crab broodstock from the fast growth crablet group was able to produce larvae with the hatching rate approximatly $98 \%$ and produced $1.410 .000 \pm 137885$ ind. larvae. It was higher than $926.808 \pm 328.212$ ind (hatching rate $67,51 \pm 25,92 \%$ ) larvae produced by their mother. While slow growth crablet group until fifth months period of culture in brackishwater pond not any one female mud crab with gonadal mature stage.

\section{Acknowledgment}

This research is funded by the Aquaculture Research Program DIPA 2017, Research Institute for Coastal Aquaculture and Fisheries Extension, Maros, Ministry of Marine Affairs and Fisheries. We would like to thank Awaludin, Sainal, Baso Amin and Muhammad Syakaria for their assistance during the research.

\section{References}

Azra, M. N., and Mhd. Ikhwanuddin, 2016. A review of maturation diets for mud crab genus Scylla broodstock: Present research, problems and future perspective. Saudi Journal of Biological Sciences 23(2): 257267.

Baliao, D. D. 2003. Mud crab growout in ponds and pens. SEAFDEC Asian Aquaculture 25(3): 21

Churchill, G. J. 2003. An investigation into the captive spawning, egg characteristics and egg quality of the mud crab (Scylla serrata) in South Africa. Master Thesis in Rhodes University, Afrika Selatan. $111 \mathrm{hlm}$.

Gunarto dan I. Rusdi, 1993. Budidaya kepiting bakau di tambak pada padat tebar berbeda. Jurnal Penelitian Budidaya Pantai 9 (3) : $7-11$.

Gunarto, Muliani dan A.Mansyur. 2010. Pengaruh aplikasi sumber $\mathrm{C}$ karbohidrat (tepung tapioka) dan fermentasi probiotik pada budidaya udang windu, Penaeus monodon pola intensif di tambak. Jurnal Riset Akuakultur 5(3) : 393-409.

Gunarto dan H. Suryanto. 2014. Budidaya kepiting bakau Scylla olivacea and scylla tranquebarica hasil pembenihan, di tambak. Proceeding Seminar Tahunan, Fakultas Pertanian Jurusan Perikanan Universitas Gadjah Mada, Yogyakarta.

Gunarto, dan Herlinah. 2015. Tingkat produksi crablet kepiting bakau Scylla paramamosain dengan pemberian pakan diperkaya dengan HUFA dan vitamin C pada fase larva. J. Ilmu dan Teknologi Kelautan Tropis, 7(2):511-520.

Gunarto, Muhammad Nur Syafaat, Herlinah, Andi Parenrengi, d a n Akhmad Mustafa. 2016. Aspek biologi dan teknik produksi benih kepiting bakau Scylla spp. Badan Penelitian dan Pengembangan Kelautan dan Perikanan, Kementerian Kelautan dan Perikanan, 62 Hlm.

Gunarto, M. N. Syafaat, Herlinah, Sulaeman, and Muliani. 2018. The effects of an artificial commercial feed supplementation on larval rearing and crablet production of mud crab scylla tranquebarica. Indonesian Aquaculture Journal, 13 (1), 2018, 13-21.

Hendrajat, E. A dan Gunarto. 2013. pertumbuhan kepiting bakau (Scylla olivacea dan Scylla paramamosain) hasil pembenihan Balai penelitian dan Pengembangan Budidaya Air Payau Maros. Prosiding Seminar Nasional Tahunan $X$ Hasil Penelitian Perikanan dan Kelautan Tahun 2013. Jurusan Perikanan dan Kelautan, Fakultas Pertanian Universitas Gadjah Mada. Hal : $1-6$. 
Karim, M. Y. 2006. Respon fisiologis larva kepiting bakau (Scylla serrata) yang diberi nauplius Artemia hasil bioenkapsulasi dengan asam lemak -3 Hufa. Jurnal Protein. 13 (1) : $74-80$.

Macintosh, D. J., Thongkum, C., Swamy, K., Cheewasedtham, C., and N. Paphavisit. 2008. Broodstock management and thepotential to improve the exploitation of mangrove crabs, Scylla serrata (Forskal), throughpond fattening in Ranong, Thailand. Aquaculture Research $24(2): 261-269$. DOI : 10.1111 / j. 13652019.1993 tb00549

Mia, M. Y., and M. M. R. Shah. 2010. Effect of salinity on the survival and growth of mud crabling, Scylla serrata. Univ. j. zool. Rajshahi. Univ. 29 : 29-32.

Sandeep, P. and R. R. Kurva. 2014. Effect of water quality parameters on growth and survivability of mud crab (Scylla tranquebarica) in gro out culture at Kakinada coast, Andhra Pradesh. International Journal of Fisheries and Aquatic Studies 2 (2): 163-166.

Siahainenia, L., Bengen, D. G., Affandi, R., Wresdiyati, T., dan I. Supriatna. 2007. Studi aspek reproduksi kepiting bakau (Scylla spp.) melalui percobaan pembenihan dengan perlakuan ablasi tangkai mata. Ichthyos 7(1): 55-63.

Syafaat, M. N dan Gunarto. 2018. Budidaya pembesaran kepiting bakau Scylla tranquebarica (fabricius, 1798) hasil pembenihan pada lokasi tambak yang berbeda. Media Akuakultur, 13 (1), 2018, 21-30

Shigeki, D., and K. Hamazaki. 2012. Effect of salinity and dietary n-3 higly unsaturated fatty acids on the survival, development, and morphogenesis of the larvae of laboratory reared mud crab Scylla serrata(decapoda Portunidae) Aquaculture International 19 (2) : 323 - 338.

Suprayudi, M. A., Takeuchi, T., K. Hamazaki and J. Hirokawa. 2002. Effect of N3HUFA content in rotiferason thedevelopment and survival of mud crab, Scylla serrata, larvae. Suisanzoshoku 50(2): 205-212.

Suprayudi, M. A., Takeuchi, T and K. Hamazaki. 2004. Effect of artemia enriched with eicosapentaenoid and docosahexaenoic acid on survival and occurence of moulting failure in megalop larvae of the mud crab Scylla serrata. Fisheries science 70 (4): 650-658.

Truong, T., N., Mathieu, W., Tran, C. B., Hoang, P. T., Nguyen, V. D., and P. Sorgeloos. (2007) Improved techniques for rearing mud crab Scylla paramamosain (estampador 1949) larvae. Aquaculture Research 38 : 1539-1553. 